Original Research Paper

\title{
A Greater dose of Ractopamine Hydrochloride Enhances Feedlot Performance and Impacts Carcass Characteristics of Calf-Fed Holstein Steers
}

\author{
${ }^{1}$ Jerilyn E. Hergenreder, ${ }^{2}$ Jonathon L. Beckett, ${ }^{3}$ Zachary K. Smith and ${ }^{1}$ Bradley J. Johnson \\ ${ }^{1}$ Department of Animal and Food Sciences, Texas Tech University, Lubbock, TX 79409, USA \\ ${ }^{2}$ Beckett Consulting Services, Fort Collins, CO 80524, USA \\ ${ }^{3}$ Department of Animal Science, South Dakota State University, Brookings, SD 57007, USA
}

\author{
Article history \\ Received: 21-01-2021 \\ Revised: 03-03-2021 \\ Accepted: 25-02-2021 \\ Corresponding Author: \\ Bradley. J. Johnson \\ Department of Animal and \\ Food Sciences, Texas Tech \\ University, Lubbock, TX \\ 79409 \\ Email: bradley.johnson@ttu.edu
}

\begin{abstract}
The objective was to evaluate the effects of supplementing ractopamine $\mathrm{HCl}$ at the rate of $400 \mathrm{mg} \mathrm{steer}^{-1}$ daily in the final $28 \mathrm{~d}$ of the feeding period on growth performance and carcass characteristics of Holstein steers. Steers $(n=1,498$; initial BW $=547 \mathrm{~kg}$ ) were randomly assigned to pens (10 pens/treatment) and to a treatment: (1) $0 \mathrm{mg} \cdot \mathrm{steer}^{-1} \cdot \mathrm{d}^{-1}$ of RH (CON); (2) Ractopamine $\mathrm{HCl}$ fed at $400 \mathrm{mg} \cdot \mathrm{steer}^{-1} \cdot \mathrm{d}^{-1}$ of RH (RH) for evaluation over a $28 \mathrm{~d}$ period. Steers were fed a finishing diet based on steam-flaked corn and alfalfa hay. Dry matter intake decreased, Average Daily Gain (ADG) was increased and improved feed efficiency $(P<0.05)$ was noted in RH steers. Steers supplemented with RH had heavier final Body Weight (BW) and HCW, greater Dressing Percentage (DP) and larger Longissimus Muscle $(\mathrm{LM})$ area $(P<0.05)$. Ractopamine $\mathrm{HCl}$ steers had improved yield grades, as evidenced by a greater percentage of yield grade 1 and a decreased percentage of yield grade $3(P<0.05)$ carcasses. Steers supplemented RH had a decreased percentage of cattle grading USDA Choice and a greater percent grading USDA Select $(P<0.05)$. These data indicate that $400 \mathrm{mg} \cdot \mathrm{steer}^{-1}$ daily of ractopamine $\mathrm{HCl}$ fed to Holstein steers may improve feedlot phase growth performance, DP, HCW and LM area while having minimal impact on USDA quality grade distribution.
\end{abstract}

Keywords: Beta-Adrenergic Agonist, Carcass Grade, Feedlot Growth Performance, Holstein Steer, Ractopamine Hydrochloride

\section{Introduction}

Beta-Adrenergic Agonists (BAA) are repartitioning agents that increase muscle accretion and decrease fat accumulation while simultaneously improving feed efficiency in finishing cattle (Sissom et al., 2007). Oral administrations of BAA have been reported to increase lean tissue deposition and decrease fat accretion in cattle, pigs, poultry and sheep (Mersmann, 1998). These BAA are a relatively new technology utilized in the U.S. beef industry to improve feedlot growth performance (Gruber et al., 2007; Winterholler et al., 2007; Vogel et al., 2009; Bass et al., 2009; Scramlin et al., 2010) and carcass characteristics (Gruber et al., 2007; Sissom et al., 2007; Vogel et al., 2009; Boler et al., 2012). Ractopamine $\mathrm{HCl}$ (RH: Optaflexx ${ }^{\circledR}$; Elanco Animal Health, Greenfield, IN) was the first BAA approved for use in beef cattle, fed for the final 28 to $42 \mathrm{~d}$ of the finishing period in 2003 by the U.S. FDA (Gruber et al., 2007; Vogel et al., 2009).

There are more than 3 million Holstein steers available for feeding each year and these cattle represent a substantial portion of feedlot cattle in the U.S. (Duff and Anderson, 2007; Duff and McMurphy, 2007). Feeding Holsteins has become more popular due to their lack of genetic diversity, predictable gains and ability produce lean, high quality carcasses (Young et al., 1978; Thonney, 1987; Duff and Anderson, 2007). However, Holsteins generally have smaller LMA and decreased DP (Duff and Anderson, 2007). Other methods currently utilized to increase lean deposition and improve efficiency include the use of anabolic hormone implants (Thonney, 1987).

Ractopamine $\mathrm{HCl}$ fed to finishing Holstein steers during the finishing phase has been reported to positively impact feedlot growth performance, HCW and LMA 
with minimal impacts on quality grade when fed at concentrations of 200 to $300 \mathrm{mg}$ steer $^{-1}$ daily for 28 to 36 d prior to harvest (Bass et al., 2009; Vogel et al., 2009). As mentioned above, multiple studies have elucidated the effects of 200 to $300 \mathrm{mg}$ RH daily; however, to our knowledge, no research has observed the effects of feeding a greater concentration of RH.

Therefore, the objective of this study was to evaluate the effects of feeding $\mathrm{RH}$ at a concentration of $400 \mathrm{mg} \cdot \mathrm{steer}^{-1}$ daily for the last $28 \mathrm{~d}$ of the feeding period on feedlot performance and carcass characteristics of Holstein steers.

\section{Materials and Methods}

\section{Experimental Location and Ethics}

All procedures related to cattle handling and care were done according to the Guide for the Care and Use of Agricultural Animals in Agricultural Research and Teaching described by (FASS, 1999). This study was conducted at a commercial beef cattle feedlot and abattoir in Brawley, CA.

\section{Animals and Management}

Holstein steers $(\mathrm{n}=1498)$ were sourced in southern $\mathrm{CA}$ and were fed in a commercial feed yard approximately 310 days prior to the onset of this study. Cattle used in the present experiment were of good health prior to the initiation of the trial. Trained personnel assessed health and wellbeing daily throughout the course of the study. Initial processing of steers occurred prior to study initiation and cattle were subjected to vaccination and health and intake management practices in accordance with the protocols of the feedlot which are typical for Holstein steers fed in the Southwest U.S. Rations were formulated to meet or exceed the (NRC, 1996) requirements for growing and finishing beef cattle. Finisher diets were formulated to contain approximately $12.5 \%$ crude protein, $3.0 \%$ nonprotein nitrogen and $10 \%$ total fat (Table 1). Treatment diets were fed ad libitum throughout the study. Complete ration composition profiles were obtained 6 times throughout the study (Table 1). Individual ration samples were sent to SDK Laboratory (Hutchinson, KS) for analyses and tabular ingredient energy values were used for determination of dietary net energy content (NRC, 1996). The sample were assayed for moisture, Crude Protein (CP), Acid Detergent Fiber (ADF), Ether Extract (EE), Calcium (Ca), Phosphorus (P), potassium (K) and zinc (Table 1). At the initiation of the trial, samples of the medicated top dress were analyzed for RH (Covance Labs, Elanco Assays-418, Greenfield, IN). Pens were observed daily by trained personnel to identify and remove steers with observable signs or symptoms of health and/or lameness issues.

\section{Experimental Design and Treatments}

Steers were randomized to study pens by receiving lot using a gate-cut procedure. Each replicate $(n=10)$ came from a lot that was gate-cut to form 2 pens (1 pen/treatment). Steers were blocked by lot and slaughter date. A total of 20 pens $(n=75$ head/pen) were used and randomly assigned to one of two treatments: (1) 0 $\mathrm{mg} \cdot \mathrm{steer}^{-1} \cdot \mathrm{d}^{-1}$ of $\mathrm{RH}(\mathrm{CON} ; \mathrm{n}=10$ pens) or 400 $\mathrm{mg} \cdot \mathrm{steer}^{-1} \cdot \mathrm{d}^{-1}$ of $\mathrm{RH}$ (RH; $\mathrm{n}=10$ pens). Treatment diets were administered the final $28 \mathrm{~d}$ of the finishing period. Upon trial initiation, steers were weighed by pen on a platform scale (initial BW was reduced by $4 \%$ to account for digestive tract fill). Steers in the RH treatment were administered RH via medicated top dress pellet. Medicated top dress consisted of $54.5 \mathrm{~kg} / \mathrm{ton} \mathrm{RH}$ pellet individually added to the bunk of each of the RH treatment pens daily. Ractopamine $\mathrm{HCl}$ concentration on average was $37.9 \mathrm{~g} / \mathrm{ton}$ of DM (400 mg/9.62 kg of dry feed).

\section{Harvest and Carcass Evaluation}

Steers were weighed by pen on a platform scale (final BW was reduced by $4 \%$ to represent a standard industry shrink) prior to shipment to the abattoir. Steers were transported to a nearby abattoir in southern CA, where they were harvested under USDA-FSIS inspection. Pens of cattle were maintained as lots when presented for slaughter. Trained personnel tracked individual identity throughout the harvest procedure. Carcasses were chilled approximately 36 $\mathrm{h}$ prior to grading. Individual carcass measurements included HCW, 12th rib fat depth (BF), LMA, KPH \% and Marbling Score (MS) determined via a digital camera grading system. Yield grade and quality grade information was recorded as assigned by USDA. Dressing percentage for each pen was calculated as the mean HCW/mean shrunk ( $4 \%$ pencil shrink) live weight $\times 100$.

\section{Statistical Analysis}

Data were analyzed using the mixed procedure of SAS (version 9.3, SAS Institute, Inc.; Cary, NC). The model included block and harvest date as random effects and treatment served as a fixed effect. Pen served as the experimental unit for feedlot growth performance and carcass characteristics. Initial weight was used as a covariate (unstructured variance). Treatment means were separated using a single degree of freedom comparisons protected by a significant $(\mathrm{P} \leq 0.05)$ F-test. Categorical data (USDA YG and QG) data were analyzed via the GLIMMIX procedure of SAS. Initial weight served as a covariate (unstructured variance) in categorical data as well. Data are presented as least squares means plus or minus the standard error of the mean. An $\alpha 0.05$ was used to determine significance and tendencies were discussed between and $\alpha$ of 0.06 and 0.10 . 
Table 1: Ingredient and chemical composition (\%, DM basis) of the experimental designs ${ }^{1,2}$

\begin{tabular}{|c|c|c|}
\hline \multirow[b]{2}{*}{ Item } & \multicolumn{2}{|c|}{ Treatments } \\
\hline & Control & $\mathrm{RAC}^{3}$ \\
\hline Wheat straw & 3.56 & 3.56 \\
\hline Sudan hay & 6.68 & 6.68 \\
\hline Corn-steam flaked & 57.94 & 51.36 \\
\hline Dried distillers grains & 12.32 & 12.32 \\
\hline Bakery waste & 8.70 & 8.70 \\
\hline Yellow grease & 4.99 & 4.99 \\
\hline Ractopamine premix & 0.00 & 6.58 \\
\hline Finisher supplement & 5.81 & 5.81 \\
\hline Net Energy for Maintenance, Mcal $/ \mathrm{kg}$ & 2.14 & 2.14 \\
\hline Net Energy for Gain, Mcal/kg & 1.53 & 1.53 \\
\hline \multicolumn{3}{|l|}{ Analyzed composition } \\
\hline Dry Matter, $\%$ & 82.82 & 82.82 \\
\hline Crude Protein, $\%$ & 13.31 & 13.31 \\
\hline Acid Detergent Fiber, $\%$ & 9.83 & 9.83 \\
\hline Fat, \% & 9.80 & 9.80 \\
\hline Calcium, $\%$ & 0.79 & 0.79 \\
\hline Phosphorus, $\%$ & 0.39 & 0.39 \\
\hline Potassium, \% & 0.84 & 0.84 \\
\hline Zinc, ppm & 97.61 & 97.61 \\
\hline
\end{tabular}

${ }^{1}$ Diets were formulated to meet or exceed NRC (1996) requirements for growing-finishing beef cattle.

${ }^{2}$ Diets contained $33.3 \mathrm{~g} /$ ton monensin (Rumensin: Elanco, Greenfield, IN).

${ }^{3}$ Finisher diet formulated to contain $400 \mathrm{mg} \cdot \mathrm{steer}^{-1} \cdot \mathrm{d}^{-1}$ ractopamine $\mathrm{HCl}$ (Optaflexx: Elanco Animal Health, Greenfield, IN).

\section{Results and Discussion}

Dry Matter Intake (DMI) was decreased by 0.5 $\mathrm{kg} \cdot$ steer $\cdot \mathrm{d}^{-1}(P<0.05$; Table 2$)$ in $\mathrm{RH}$ cattle. This data is similar to that reported by (Quinn et al., 2008) when 300 $\mathrm{mg} \cdot$ heifer $^{-1} \cdot \mathrm{d}$ of $\mathrm{RH}$ was administered to heifers for $28 \mathrm{~d}$ prior to harvest. In contrast to data from this study, a decrease in DMI has not been observed in several other studies (Walker et al., 2006; Winterholler et al., 2008; Strydom et al., 2009) in which no difference in DMI was reported when $\mathrm{RH}$ was fed. The RH steers had greater Average Daily Gain (ADG; $1.61 \mathrm{~kg}$ Vs. $1.38 \mathrm{~kg} \pm 0.08$, respectively; $P<0.05$ ) when compared to $\mathrm{CON}$ steers. In other studies, ADG was increased 0.02 to $0.63 \mathrm{~kg}$ when $\mathrm{RH}$ was fed to steers and heifers at 200 or $300 \mathrm{mg} \cdot \mathrm{steer}$ or heifer ${ }^{-1} \cdot \mathrm{d}^{-1}$ for 28 to $38 \mathrm{~d}$ (Gruber et al., 2007; Sissom et al., 2007; Winterholler et al., 2007; Vogel et al., 2009; Bass et al., 2009; Scramlin et al., 2010). Due to increased ADG, RH steers had heavier final live weights ( $7 \mathrm{~kg}$ increase; $P<0.05)$. Increased final BW has also been reported by (Bass et al., 2009; Vogel et al., 2009) who reported Holstein steers administered RH, exhibited increases in final live weight by 7 to $12 \mathrm{~kg}$. Other studies have reported a 4.7 to $11.0 \mathrm{~kg}$ increase in final live weights compared to non-supplemented cattle when $\mathrm{RH}$ was fed to native beef steers and heifers (Walker et al., 2006; Winterholler et al., 2007; Gruber et al., 2007; Scramlin et al., 2010). Furthermore in this study, RH steers had a lower $\mathrm{F}: \mathrm{G}$ ratio (5.98 Vs. 7.39 \pm 0.21 ; $P<0.05)$ than $\mathrm{CON}$ steers. These data are similar to that described by (Gruber et al., 2007; Winterholler et al., 2007; Vogel et al., 2009), that reported steers administered RH increased gain to feed ratio.

The RH steers had greater DP $(P<0.05)$ and HCW $(P<0.05)$ compared to CON steers (Table 3). Boler et al. (2012) also reported increases in DP and HCW when steers were administered RH. Control steers had a smaller LMA $(P<0.05)$ and tended to have increased BF $(P<0.05)$, thus increasing the calculated YG $(P<0.05)$ compared to RH steers (2.1 Vs. 2.3 \pm 0.04$)$. A decrease in Yield Grade (YG) has been previously reported by (Sissom et al., 2007; Vogel et al., 2009) when utilizing $\mathrm{RH}$ in steers and heifers. The RH steers had a greater percentage of YG 1 (9.27 Vs. 3.08 $\pm 1.14 \% ; P<0.05)$ and a decreased percentage of YG 3 (23.79 Vs. $37.29 \pm 3.29 \% ; P<0.05)$ carcasses when compared to CON (Table 4). Similarly, (Gruber et al., 2007; Vogel et al., 2009) reported an increase in YG 1 and 2 carcasses when $\mathrm{RH}$ was administered. There was no difference in the percentage of YG 2 (65.86 Vs. 59.09 $\pm 3.32 \%$; $P>0.10)$ or YG $4 \quad(1.08$ Vs. $0.53 \pm 0.29 \% ; \quad P>0.10)$ between treatments. There was no difference in marbling score $(P>0.10)$ between treatments. Likewise, previous studies have also reported no difference in marbling score when steers or heifers were administered $\mathrm{RH}$ (Walker et al., 2006; Gruber et al., 2007; Sissom et al., 
2007; Winterholler et al., 2007; Strydom et al., 2009; Scramlin et al., 2010; Boler et al., 2012). A change in the distribution of quality grades was observed between treatments. Control steers had a greater percentage of USDA Choice when compared to RH (63.26 Vs.
$56.74 \pm 2.32 \% ; P<0.05)$ and a decreased percentage of USDA Select $(34.94$ Vs. $41.69 \pm 2.30 \% ; P<0.05)$ carcasses. In contrast to data obtained in this study, (Boler et al., 2012; Gruber et al., 2007) reported no differences in carcass quality grade distributions.

Table 2: Growth performance response of Holstein steers to ractopamine hydrochloride dosage

\begin{tabular}{|c|c|c|c|c|}
\hline \multirow[b]{2}{*}{ Item } & \multicolumn{4}{|c|}{ Treatments $^{1}$} \\
\hline & Control & RAC & $\mathrm{MSE}^{2}$ & $P$-Value \\
\hline Initial weight, $\mathrm{kg}^{4,5}$ & 547.000 & 547.000 & 7.17 & 0.927 \\
\hline Final weight, $\mathrm{kg}^{3,4,5}$ & 587.000 & 594.000 & 2.21 & $<0.001$ \\
\hline Dry Matter Intake (DMI), $\mathrm{kg}^{3,4}$ & 10.070 & 9.570 & 0.30 & 0.010 \\
\hline Average Daily Gain (ADG), $\mathrm{kg}^{3,4}$ & 1.380 & 1.610 & 0.08 & $<0.001$ \\
\hline $\mathrm{DMI} / \mathrm{ADG}^{3,4}$ & 7.390 & 5.980 & 0.21 & $<0.001$ \\
\hline ADG/DMI ${ }^{6}$ & 0.135 & 0.167 & - & - \\
\hline
\end{tabular}

${ }^{1}$ Control $=0 \mathrm{mg} \cdot \mathrm{steer}^{-1} \cdot \mathrm{d}^{-1}$ ractopamineHCl; RAC $=400 \mathrm{mg} \cdot \mathrm{steer}^{-1} \cdot \mathrm{d}^{-1}$ ractopamine $\mathrm{HCl}($ Optaflexx: Elanco Animal Health, Greenfield, IN)

${ }^{2}$ Mean square error

${ }^{3}$ Initial weight included as covariate

${ }^{4}$ Weight multiplied by 0.96

${ }^{5}$ Harvest date included as covariate

$61 / \mathrm{F}: \mathrm{G}$

Table 3: Effect of ractopamine hydrochloride on carcass traits of Holstein steers

\begin{tabular}{|c|c|c|c|c|}
\hline \multirow[b]{2}{*}{ Item } & \multicolumn{4}{|c|}{ Treatments $^{1}$} \\
\hline & Control & RAC & $\mathrm{MSE}^{2}$ & $P$-Value \\
\hline Dressing percent $^{3}$ & 61.40 & 62.10 & 0.17 & 0.007 \\
\hline $\mathrm{HCW}, \mathrm{kg}^{3}$ & 360.00 & 368.00 & 4.13 & 0.005 \\
\hline Marbling score sc $^{3,4}$ & 430.00 & 425.00 & 3.70 & 0.344 \\
\hline LMA, square $\mathrm{cm}^{3,5}$ & 74.10 & 78.20 & 0.08 & $<0.001$ \\
\hline Calculated $\mathrm{YG}^{3,5}$ & 2.30 & 2.10 & 0.04 & 0.001 \\
\hline $12^{\text {th }}$ rib back-fat, $\mathrm{cm}^{3}$ & 0.66 & 0.61 & 0.01 & 0.070 \\
\hline
\end{tabular}

${ }^{1}$ Control $=0 \mathrm{mg} \cdot \mathrm{steer}^{-1} \cdot \mathrm{d}^{-1}$ ractopamine $\mathrm{HCl} ; \mathrm{RAC}=400 \mathrm{mg} \cdot \mathrm{steer}^{-1} \cdot \mathrm{d}^{-1}$ ractopamine $\mathrm{HCl}($ Optaflexx: Elanco Animal Health, Greenfield, IN)

${ }^{2}$ Mean square error

${ }^{3}$ Harvest date included as covariate

${ }^{4}$ Marbling Score; Slight $=300$, Small $=400$, Modest $=500$

${ }^{5}$ Calculated $\mathrm{YG}=2.50+(2.50 *$ adjusted fat thickness, in $)+(0.20 *$ percent $\mathrm{KPH})+(0.0038 * \mathrm{HCW}$, pounds $)-\left(0.32 * \mathrm{REA}\right.$, in $\left.{ }^{2}\right)$.

Table 4 Effect of ractopamine hydrochloride dosage on quality and Yield Grade (YG) distribution of Holstein steers

\begin{tabular}{|c|c|c|c|c|}
\hline \multirow[b]{2}{*}{ Item $^{3}$} & \multicolumn{4}{|c|}{ Treatments ${ }^{1}$} \\
\hline & Control & RAC & $\mathrm{MSE}^{2}$ & $P$-Value \\
\hline YG 1,\% & 3.08 & 9.27 & 1.14 & $<0.001$ \\
\hline YG 2, \% & 59.09 & 65.86 & 3.32 & 0.126 \\
\hline YG 3, \% & 37.29 & 23.79 & 3.29 & 0.005 \\
\hline YG 4, \% & 0.53 & 1.08 & 0.29 & 0.126 \\
\hline Prime, $\%$ & 1.22 & 1.76 & 0.28 & 0.190 \\
\hline Choice, \% & 63.26 & 56.74 & 2.32 & 0.042 \\
\hline Select, \% & 34.94 & 41.69 & 2.30 & 0.035 \\
\hline No Roll, \% & 1.00 & 2.21 & 0.40 & 0.153 \\
\hline
\end{tabular}

${ }^{1}$ Control $=0 \mathrm{mg} \cdot \mathrm{steer}^{-1} \cdot \mathrm{d}^{-1}$ ractopamine $\mathrm{HCl} ; \mathrm{RAC}=400 \mathrm{mg} \cdot \mathrm{steer}^{-1} \cdot \mathrm{d}^{-1}$ ractopamine $\mathrm{HCl}($ Optaflexx: Elanco Animal Health, Greenfield, IN)

${ }^{2}$ Mean square error

${ }^{3}$ Harvest date included as covariate 
Administering a high dose of RH to Holstein steers for the final $28 \mathrm{~d}$ of the feeding period improved feedlot growth performance, but the greatest advantages may be observed in carcass parameters. In this study, supplementing steers with $400 \mathrm{mg} \cdot$ steer $^{-1} \cdot \mathrm{d}^{-1}$ of RH for $28 \mathrm{~d}$ increased DP, HCW, LMA and did not affect marbling score, thus increasing the value and profitability of the carcass for both the packer and producer. When comparing this study to other studies that fed 200 or $300 \mathrm{mg} \cdot \mathrm{steer}^{-1} \cdot \mathrm{d}^{-1} \mathrm{RH}$ to Holstein steers, the greatest advantages were observed in carcass parameters. Administering a concentration of $400 \mathrm{mg} \cdot \mathrm{steer}^{-1} \cdot \mathrm{d}^{-1} \mathrm{RH}$ to Holsteins, increased DP by 0.7 percent, $\mathrm{HCW}$ by $8 \mathrm{~kg}$, LMA by $4.1 \mathrm{~cm}^{2}$ and did not affect marbling scores. In other Holstein studies administering 200 or 300 $\mathrm{mg} \cdot$ steer $^{-1} \cdot \mathrm{d}^{-1} \mathrm{RH}$ increased HCW by up to $6 \mathrm{~kg}$, LMA 2.78 $\mathrm{cm}^{2}$ and did not change DP (Bass et al., 2009; Vogel et al., 2009). Furthermore, this study had a greater increase on the percentage of YG $1(6.19 \%)$ and decrease of YG $3(13.5 \%)$ carcasses compared to (Vogel et al., 2009) who reported a $4.5 \%$ increase in YG 1 and an $8 \%$ decrease in YG 3 carcasses.

\section{Conclusion}

This study demonstrates that administering 400 $\mathrm{mg} \cdot \mathrm{steer}^{-1} \cdot \mathrm{d}^{-1}$ of $\mathrm{RH}$ to Holstein steers during the final $28 \mathrm{~d}$ on feed enhances daily gain and gain efficiency, as well as increases carcass muscularity. The lack of detrimental impact on marbling when RH was fed at a rate of 400 $\mathrm{mg} \cdot \mathrm{steer}^{-1} \cdot \mathrm{d}^{-1}$ to calf-fed Holsteins allows for enhanced productivity without detriment to marbling scores compared to commonly used feeding rates of $\mathrm{RH}$.

\section{Acknowledgment}

Supported by the Gordon W. Davis Regents Chair in Meat Science and Muscle Biology Endowment at Texas Tech University, Lubbock.

\section{Author Contributions}

Jerilyn E. Hergenreder and Zachary K. Smith: Formal analysis and writing the original version of the manuscript.

Jonathon L. Beckett: Trial execution, study design and editing the final version of the manuscript.

Bradley J. Johnson: Trial execution, formal analysis, editing the final version of the manuscript.

\section{Ethics}

All procedures were done according to the Guide for the Care and Use of Agricultural Animals in Agricultural Research and Teaching described by (FASS, 1999).

\section{References}

Bass, P. D., Beckett, J. L., \& Delmore Jr, R. J. (2009). Case study: Effects of ractopamine in combination with various hormone implant regimens on growth and carcass attributes in calf-fed Holstein steers. Professional animal scientist. https://agris.fao.org/agrissearch/search.do?recordID=US201301615809

Boler, D. D., Shreck, A. L., Faulkner, D. B., Killefer, J., McKeith, F. K., Homm, J. W., \& Scanga, J. A. (2012). Effect of ractopamine hydrochloride (Optaflexx) dose on live animal performance, carcass characteristics and tenderness in early weaned beef steers. Meat Science, 92(4), 458-463. https://www.sciencedirect.com/science/article/abs/pi i/S0309174012001751

Duff, G. C., \& Anderson, P. T. (2007). Comparative performance of Holstein vs. beef breeds in the feedlot. In Proc. 22nd Annu. Southwest Nutr. Manage. Conf., Univ. of Arizona, Tucson. Univ. Arizona, Tucson (pp. 27-36).

Duff, G. C., \& McMurphy, C. P. (2007). Feeding Holstein steers from start to finish. Veterinary Clinics of North America: Food Animal Practice, 23(2), 281-297. https://www.sciencedirect.com/science/article/abs/pii/S 0749072007000242

FASS. (1999). Guide for the care and use of agricultural animals in agricultural research and teaching. Federation of Animal Science Societies. https://www.asas.org/docs/default-source/defaultdocumentlibrary/agguide_4th.pdf?sfvrsn=56b44ed1_2

Gruber, S. L., Tatum, J. D., Engle, T. E., Mitchell, M. A., Laudert, S. B., Schroeder, A. L., \& Platter, W. J. (2007). Effects of ractopamine supplementation on growth performance and carcass characteristics of feedlot steers differing in biological type. Journal of Animal Science, 85(7), 1809-1815. https://academic.oup.com/jas/articleabstract/85/7/1809/4788888

Mersmann, H. J. (1998). Overview of the effects of $\beta$ adrenergic receptor agonists on animal growth including mechanisms of action. Journal of Animal Science, 76(1), 160-172. https://academic.oup.com/jas/articleabstract/76/1/160/4625179

NRC. (1996). Nutrient Requirements of Beef Cattle. 7th ed. Natl. Acad. Press, Washington, DC. National Research Council.

Quinn, M. J., Reinhardt, C. D., Loe, E. R., Depenbusch, B. E., Corrigan, M. E., May, M. L., \& Drouillard, J. S. (2008). The effects of ractopamine-hydrogen chloride (Optaflexx) on performance, carcass characteristics and meat quality of finishing feedlot heifers. Journal of Animal Science, 86(4), 902-908. https://academic.oup.com/jas/articleabstract/86/4/902/4788986 
Scramlin, S. M., Platter, W. J., Gomez, R. A., Choat, W. T., McKeith, F. K., \& Killefer, J. (2010). Comparative effects of ractopamine hydrochloride and zilpaterol hydrochloride on growth performance, carcass traits and longissimus tenderness of finishing steers. Journal of Animal Science, 88(5), 1823-1829. https://academic.oup.com/jas/articleabstract/88/5/1823/4745652

Sissom, E. K., Reinhardt, C. D., Hutcheson, J. P., Nichols, W. T., Yates, D. A., Swingle, R. S., \& Johnson, B. J. (2007). Response to ractopamine- $\mathrm{HCl}$ in heifers is altered by implant strategy across days on feed. Journal of Animal Science, 85(9), 2125-2132. https://academic.oup.com/jas/articleabstract/85/9/2125/4778330

Strydom, P. E., Frylinck, L., Montgomery, J. L., \& Smith, M. F. (2009). The comparison of three $\beta$-agonists for growth performance, carcass characteristics and meat quality of feedlot cattle. Meat Science, 81(3), 557-564. https://www.sciencedirect.com/science/article/abs/pii/S 0309174008003434

Thonney, M. L. (1987). Growth, feed efficiency and variation of individually fed Angus, Polled Hereford and Holstein steers. Journal of Animal Science, $65(1), \quad 1-8$. https://academic.oup.com/jas/articleabstract/65/1/1/4662290

Vogel, G. J., Duff, G. C., Lehmkuhler, J., Beckett, J. L., Drouillard, J. S., Schroeder, A. L., ... \& Laudert, S. B. (2009). Effect of ractopamine hydrochloride on growth performance and carcass traits in calf-fed and yearling Holstein steers fed to slaughter. The Professional Animal Scientist, 25(1), 26-32. https://www.sciencedirect.com/science/article/abs/pi i/S1080744615306756
Walker, D. K., Titgemeyer, E. C., Drouillard, J. S., Loe, E. R., Depenbusch, B. E., \& Webb, A. S. (2006). Effects of ractopamine and protein source on growth performance and carcass characteristics of feedlot heifers. Journal of Animal Science, 84(10), 2795-2800. https://academic.oup.com/jas/articleabstract/84/10/2795/4779114

Winterholler, S. J., Parsons, G. L., Reinhardt, C. D., Hutcheson, J. P., Nichols, W. T., Yates, D. A., ... \& Johnson, B. J. (2007). Response to ractopaminehydrogen chloride is similar in yearling steers across days on feed. Journal of Animal Science, 85(2), 413-419. https://academic.oup.com/jas/articleabstract/85/2/413/4779555

Winterholler, S. J., Parsons, G. L., Walker, D. K., Quinn, M. J., Drouillard, J. S., \& Johnson, B. J. (2008). Effect of feedlot management system on response to ractopamine- $\mathrm{HCl}$ in yearling steers. Journal of Animal Science, 86(9), 2401-2414. https://academic.oup.com/jas/article/86/9/2401/4789 794? $\operatorname{login}=$ true

Young, L. D., Cundiff, L. V., Crouse, J. D., Smith, G. M., \& Gregory, K. E. (1978). Characterization of biological types of cattle. VIII. Postweaning growth and carcass traits of three-way cross steers. Journal of Animal Science, 46(5), 1178-1191. https://academic.oup.com/jas/articleabstract/46/5/1178/4700764 